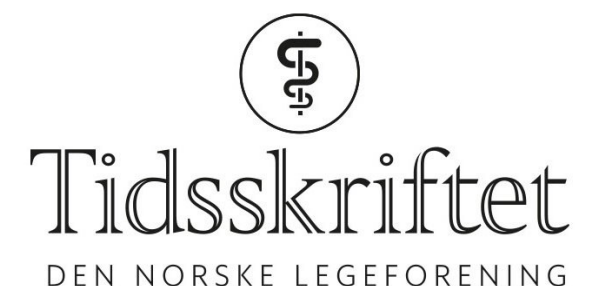

DEN NORSKE LEGEFORENING

\title{
Ingen er trygge før alle er trygge
}

LEDER

\section{JOHN-ARNE RøTTINGEN}

E-post: john-arne@rottingen.no

John-Arne Røttingen er administrerende direktør i Norges forskningsråd. Fra 1.12.202o er han ambassadør for global helse i Utenriksdepartementet og fagdirektør i Folkehelseinstituttet. Forfatteren har fylt ut ICMJE-skjemaet og oppgir ingen interessekonflikter.

I en pandemi må vi sikre tilgang til tester, vaksiner og legemidler for alle land og befolkningsgrupper. Dette krever solidaritet og internasjonalt samarbeid.

2020 går snart inn i historiebøkene. Omtrent hundre år etter spanskesyken har året vært preget av covid-19-pandemien, med over 50 millioner rapporterte smittede og nærmere 1,5 millioner døde. Fortsatt har majoriteten av jordas befolkning ved inngangen til 2021 ikke gjennomgått covid-19-infeksjon.

En ny virussykdom krever teknologiske mottiltak som tester, legemidler og vaksiner. Etter ebolaepidemien i Vest-Afrika 2014-16 etablerte Verdens helseorganisasjon (WHO) en beredskapsplattform for rask intervensjon ved epidemier, WHO R\&D Blueprint (1). Denne plattformen prioriterte noen kjente virussykdommer, men understreket behovet for å være forberedt på sykdom X - altså en hittil ukjent virussykdom. Covid-19 ble den første. WHO har koordinert responsen innen forskning og utvikling og prioritert de viktigste kunnskapsbehovene, men selve arbeidet er først og fremst gjort av forskningsmiljøer i offentlig og privat sektor verden over. Kunnskapsutviklingen har vært raskere enn noensinne tidligere.

PCR-basert diagnostikk kom på plass bare dager etter at Kina delte informasjon om virussekvensen 12. januar 2020. Nå utvikles det hurtigtester som muliggjør rask og effektiv testing. På behandlingssiden var utprøving av etablerte legemidler første strategi. Deksametason viste seg å øke overlevelsen for alvorlig syke (2), men ellers har resultatene vært skuffende (3). Neste strategi er utprøving av legemidler utviklet spesifikt for covid-19, inkludert monoklonale antistoffer.

Verden vil ikke kunne gjenoppta normal sosial og økonomisk aktivitet, handel og reiser før epidemien er under kontroll $i$ alle land

Utvikling av vaksiner har vært imponerende (4). 212 ulike vaksinekandidater er under utvikling, og hele 48 kandidater er allerede i kliniske studier, hvorav 11 har nådd fase 3 (5). De første signalene fra studiene indikerer to mRNA-vaksiner med $95 \%$ effekt (6). Det internasjonale vaksinesamarbeidet er koordinert av Coalition for Epidemic Preparedness Innovations (CEPI), som ble etablert i 2017 for å utvikle vaksiner for epidemier (7).

Verden vil ikke kunne gjenoppta normal sosial og økonomisk aktivitet, handel og reiser før epidemien er under kontroll i alle land. WHO og Europakommisjonen har ledet 
etableringen av Access to Covid-19 Tools Accelerator (ACT-A). Målet er å sikre to milliarder vaksinedoser innen utgangen av 2021 samt 500 millioner hurtigtester og 245 medisinske behandlinger (8). Kostnaden er beregnet til 340 milliarder kroner, og Norge og Sør-Afrika leder arbeidet for å sikre finansieringen gjennom offentlige, filantropiske og private bidrag. Det er fortsatt mye usikkerhet rundt vaksinene, og vaksiner vil ikke alene kunne gi kontroll på pandemien

Hovedvirkemidlet for rask tilgang til vaksiner for alle har primært vært å utvikle mange vaksiner parallelt for å sikre at én eller flere vaksiner blir godkjent. Dernest har målet vært å $\emptyset$ ke produksjonskapasiteten verden over og å starte storskalaproduksjon i forkant av en eventuell godkjenning. Til slutt har det blitt etablert kjøpekraft på vegne av fattige land. Vaksinepilaren i ACT-A har etablert en felles innkjøpsmekanisme, Covax-fasiliteten, som inngår avtaler om tilgang til vaksiner for 95 selvfinansierende land og 92 utviklingsland (9). Vaksiner for Norge er primært sikret gjennom samarbeid med EU, som har inngått flere bilaterale avtaler der kjøper tar risikoen knyttet til manglende godkjenning for de aktuelle vaksinene. Det vil være begrenset antall godkjente vaksinedoser i hele 2021 og trolig også i store deler av 2022. I et etisk rammeverk for fordeling innenfor innkjøpssamarbeidene foreslås det følgende prioritering: først redusere dødelighet, dernest minske andre helseutfall, sosiale og økonomiske konsekvenser og til slutt kontrollere smitte (10).

En trygg og effektiv vaksine er hovedstrategi for å kontrollere pandemien. Men det er fortsatt mye usikkerhet rundt vaksinene, og vaksiner vil ikke alene kunne gi kontroll på pandemien. Alle land må benytte en kombinasjon av klassiske smitteverntiltak og de nye teknologiene. Det vil kreve samarbeid og solidaritet. Infeksjoner er sosiale samfunnssykdommer. Sosiale fordi de drives av sosiale forhold og strukturer. Samfunnssykdom fordi vi alle deler den felles drivende risikoen - andelen som er smittsomme. Ingen er trygge før alle er trygge.

LITTERATUR:

1. Kieny MP, Røttingen JA, Farrar J et al. The need for global R\&D coordination for infectious diseases with epidemic potential. Lancet 2016;388: 460-1. [PubMed][CrossRef]

2. Horby P, Lim WS, Emberson JR et al. Dexamethasone in hospitalized patients with covid-19preliminary report. N Engl J Med 2020; NEJMoa2021436. [PubMed]

3. Pan H, Peto R, Karim QA et al. Repurposed antiviral drugs for COVID-19-interim WHO SOLIDARITY trial results medRxiv 2020 doi: 10.1101/2020.10.15.20209817. [CrossRef]

4. Taxt AM, Grødeland G, Lind A et al. Status for vaksineutvikling mot covid-19. Tidsskr Nor Legeforen 2020; 140. doi: 10.4045/tidsskr.20.0676. [PubMed][CrossRef]

5. World Health Organization. Draft landscape of COVID-19 candidate vaccines. 12.11.2020. https://www.who.int/publications/m/item/draft-landscape-of-covid-19-candidate-vaccines Lest 21.11.2020.

6. Cohen J. 'Incredible milestone for science.' Pfizer and BioNTech update their promising COVID-19 vaccine result. Science 2020 doi: 10.1126/science.abf7754. [CrossRef]

7. Røttingen JA, Gouglas D, Feinberg M et al. New vaccines against epidemic infectious diseases. N Engl J Med 2017; 376: 610-3. [PubMed][CrossRef]

8. Accelerator ACT. Status Report \& Plan. Geneve: World Health Organization, 2020.

https://www.who.int/publications/i/item/act-accelerator-status-report-plan Lest 8.11.2020.

9. What is COVAX. https://www.gavi.org/covax-facility\#what Lest 8.11.2020.

10. Emanuel EJ, Persad G, Kern A et al. An ethical framework for global vaccine allocation. Science 2020; 369:1309-12. [PubMed][CrossRef] 
Publisert: 14. desember 2020. Tidsskr Nor Legeforen. DOI:10.4045/tidsskr.20.0959

(C) Tidsskrift for Den norske legeforening 2020. Lastet ned fra tidsskriftet.no 